\title{
Densities of planktonic Lepeophtheirus salmonis before and after an Atlantic salmon farm relocation
}

\author{
Michael J. Penston*, Alastair J. A. McBeath, Colin P. Millar \\ Marine Scotland Science, Marine Laboratory, PO Box 101, 375 Victoria Road, Aberdeen AB11 9DB, UK
}

\begin{abstract}
Relocating Atlantic salmon Salmo salar L. farms away from important salmonid rivers is possibly a means to reduce Lepeophtheirus salmonis (Krøyer, 1837) interactions between farmed Atlantic salmon and wild salmonids. However, to date, no data have been presented on the consequences of salmon farm relocation in terms of densities of planktonic L. salmonis. Near-surface plankton were sampled at 5 stations during 2 full farming production cycles; 1 before and 1 after a salmon farm relocation within a sea loch/fjord. The relocation comprised the removal of a salmon farm and the reallocation of its fish biomass to a different farm within the same management area. Over $85 \%$ of the larval sea lice we identified in sub-samples were L. salmonis; we therefore assumed that the majority of the larvae found were of that species. Densities of L. salmonis larvae increased significantly at all stations post relocation, except at the station near the vacated farm site where mean densities of nauplii were significantly lower and mean densities of copepodids were lower without statistical significance. The removal/relocation of the salmon farm significantly reduced the production of $L$. salmonis larvae, but did not significantly reduce the infection pressure, as represented by densities of the infectious copepodid stage, at the vacated farm site. This finding indicates that planktonic $L$. salmonis were transported to the vacated farm site from sources at a minimum of 5 to $8 \mathrm{~km}$ distant.
\end{abstract}

KEY WORDS: Scotland $\cdot$ Sea lice $\cdot$ Relocation $\cdot$ Management $\cdot$ Salmon aquaculture $\cdot$ Sea trout

\section{INTRODUCTION}

Lepeophtheirus salmonis (Krøyer, 1837) is a naturally occurring marine parasite of salmonids and is a concern for farmed Atlantic salmon Salmo salar L. and wild salmonid fisheries (Costello 2009a). L. salmonis has been implicated in the decline of salmonid populations on the west coast of Ireland (Tully \& Whelan 1993, Whelan 1993), Scotland (Walker 1994) and even globally (Ford \& Myers 2008).

Farmed Atlantic salmon are put to sea from freshwater and initially bear no Lepeophtheirus salmonis infections. Escaped farmed fish, non-salmonid wild hosts and remote farms may represent sources of lice; however, Bron et al. (1993) opined that the initial louse infection of farmed Atlantic salmon smolts probably results principally from wild salmonids. L. salmonis can be found on non-salmonid fish, e.g. saithe Pollachius virens L. (Bruno \& Stone 1990) and sea bass
Dicentrarchus labrax L. (Pert et al. 2006), but there is no report of $L$. salmonis being able to complete its lifecycle on such fish. Once infected, farms can magnify infection pressure in the local environment (Murray 2009) by amplifying the potential for the parasites to encounter and infect near-by farmed and wild salmonids (Revie et al. 2009).

Planktonic sea lice larval development consists of 2 naupliar stages and 1 copepodid stage, the latter being older and more developed. Lepeophtheirus salmonis infection spreads primarily via the infective copepodid stage (Tully et al. 1993, Costelloe et al. 1995, Finstad et al. 2000), although adults, particularly males, are also known to transfer between hosts (Connors et al. 2008). Previous plankton surveys in Loch Torridon (McKibben \& Hay 2004, Penston et al. 2004, 2008a) and a coupled hydrographic-particle tracking model developed for that area (Murray \& Gillibrand 2006, Amundrud \& Murray 2009) indicate that louse larvae can be trans- 
ported several kilometres. A study in the Loch Torridon system (and elsewhere) highlighted an apparent link between salmon farming and louse burdens on wild sea trout Salmo trutta L. (Middlemas et al. 2010).

Control of Lepeophtheirus salmonis infections is managed on Atlantic salmon farms through applications of a variety of medicines and husbandry practices. The 2 most commonly used chemotherapeutants for controlling $L$. salmonis are cypermethrin and emamectin benzoate (Lees et al. 2008). Husbandry practices, such as single year-class stocking, synchronised fallow periods and coordinated louse treatments (Bron et al. 1993, Grant \& Treasurer 1993, Anonymous 2006) can be employed as measures to control L. salmonis populations and to reduce potential for farm louse interactions with wild fishes. Another proposed measure to limit sea louse interactions between wild and farmed salmonids is farm relocation (Rosenberg 2008).

To date, there are no reports presenting data on the consequences for larval sea louse distribution of relocating an Atlantic salmon farm. The objective of the present study was to determine if, and how, the relocation of a farm affected the distribution of planktonic Lepeophtheirus salmonis larvae in the Loch Torridon management area. Given that Atlantic salmon farms have been found to be significant sources of larval lice in this study area (Penston \& Davies 2009), the removal of one of the farms could be expected to reduce the densities of larval lice at the site vacated by the farm.

\section{MATERIALS AND METHODS}

Study area. The Loch Torridon system on the northwest coast of Scotland, UK, contains 3 fjordic basins; Lower Loch Torridon, Loch Shieldaig and Upper Loch Torridon. For an in-depth description of the Loch Torridon system see Gillibrand \& Amundrud (2007) and Penston \& Davies (2009). Six small rivers enter the Loch Torridon system, 3 of which contain salmonids. The Rivers Shieldaig, Balgy and Torridon (see Fig. 1) have populations of sea trout. The Rivers Balgy and Torridon also have populations of wild Atlantic salmon.

During the study period (2004 to 2008) there were initially 5 Atlantic salmon farms in Loch Torridon with maximum consented biomasses varying from 250 to $1375 \mathrm{t}$ at the start of the study (see Fig. 1). The study was carried out over $4 \mathrm{yr}$, and within that period 2 production cycles were completed at the farms. Farms 1 and 3 , in synchronous production, stocked lice-free Atlantic salmon smolts (young salmon) in March of 2004 and 2006 and harvested over a period of months during the winters of 2005 and 2007. Farms 4 and 5 stocked and harvested in synchrony with Farms 1 and 3 during the first production cycle, and thereafter these farms were used only for on-growing fish (growing fish reared elsewhere) from Farm 1. Farm 2 was stocked in September 2004, asynchronously to the other farms in the area; yet, harvesting was completed at this farm at approximately the same time as the other farms.

Farm 2 was relocated in 2006. Relocation consisted of a cessation of production at Farm 2 in February 2006, and the maximum consented biomass for Farm 2 was transferred to Farm 3 in Upper Loch Torridon. This relocation essentially removed Farm 2 and increased the size of Farm 3. Plankton sampling was therefore undertaken during 2 contrasting cycles: Cycle 1 (February 2004 to February 2006) when Farm 2 was operational, and Cycle 2 (February 2006 to February 2008) when Farm 2 had ceased production and the biomass was transferred to Farm 3.

Sampling. Between February 2004 and February 2008 plankton sampling took place approximately fortnightly on the same day at 5 sampling stations (Fig. 1). The naming of these stations is carried forward from Penston et al. (2008a). A plankton net of mouth diameter $0.5 \mathrm{~m}$ and $150 \mu \mathrm{m}$ mesh size (EFE \& GB Nets ${ }^{\circledR}$ ) was towed from a small boat at 0.0 to $0.5 \mathrm{~m}$ depth. Tow duration was between 4 and 5 min and sampled volumes were measured by a flowmeter (General Oceanics $\left.^{\circledR}\right)$ suspended in the mouth of the net. The mean sample volume in Cycle 1 was $16.80 \mathrm{~m}^{3}$ (SD $11.17 \mathrm{~m}^{3}$ ) and in Cycle 2 was $31.23 \mathrm{~m}^{3}$ (SD $9.62 \mathrm{~m}^{3}$ ). Large SDs in the volumes sampled resulted from natural seasonal variability in plankton densities. The sampled volumes in Cycle 2 were greater than in Cycle 1 as a result of collecting the samples at a greater speed $; ~ 60$ and $32 \mathrm{~cm} \mathrm{~s}^{-1}$, respectively. Samples were collected and prepared for analysis as described in Penston et al. (2008a). Extracted louse larvae were preserved in $70 \%$ ethanol.

Identification. Out of a total of 502 samples taken over the 4 yr period, 148 contained caligid copepodids and 88 contained nauplii. With reference to descriptions in Schram (2004), copepodids were identified to species in $45(30 \%)$ of the copepodid-positive samples using a high-powered inverted microscope (Zeiss ${ }^{\circledR}$, Axiovert 200). In the 2 samples that contained $>15$ copepodids, only 15 individuals were identified to species level. No attempt was made to identify the nauplii by microscopy or to distinguish between the 2 naupliar stages. We report the ratio mean density of nauplii divided by the sum of the mean density of nauplii and copepodids $(n: n+c)$ recovered at each station in each cycle to provide an index of larval demographics. Henceforward this ratio is referred to as the 'nauplius fraction'.

From a random selection of 61 of the 88 samples that contained nauplii, 1 nauplius per sample was analysed by real-time PCR. Selection of 1 nauplius per sample 
Fig. 1. Positions of sample stations $(\bullet ; A, C, E, G$ and $H)$, Atlantic salmon farms $(\square$; numbered 1, 2, 3, 4 and 5) with respective maximum biomass consent (tonnes, $\mathrm{t}$ ) in parentheses and the Rivers Shieldaig, Balgy, and Torridon in the Loch Torridon system. Insets show the position of the study area in relation to (right-hand) the British Isles and (left-hand) Scotland. *: Farm 2 was relocated to Farm 3 in Cycle 2 (February 2006 to February 2008) and the consented salmon biomass of Farm 3 increased to $1767 \mathrm{t}$

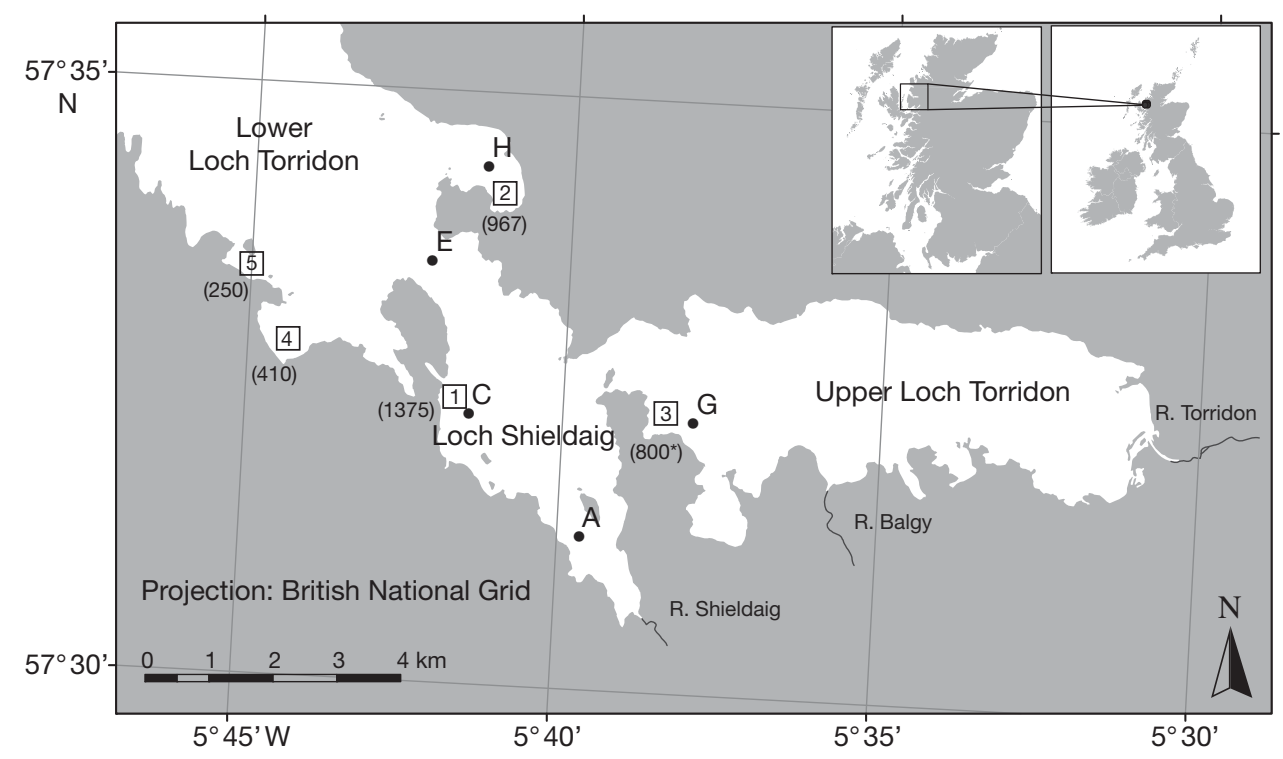

gave the species distribution from the range of populations sampled and it was not intended to identify the species composition in individual samples. In each case, the nauplius chosen for analysis was simply the first one out of the specimen vial storing the louse larvae of that sample. The DNA of individual nauplii was obtained by incubation for $3 \mathrm{~h}$ at $55^{\circ} \mathrm{C}$ in $15 \mu \mathrm{l}$ lysis buffer containing $1 \times$ Tris-EDTA (TE) buffer, $0.45 \%$ Tween 20 (Sigma), $0.45 \%$ NP40 (Sigma) and $20 \mathrm{mg}$ $\mathrm{ml}^{-1}$ proteinase-K (Sigma) followed by incubation at $95^{\circ} \mathrm{C}$ for $5 \mathrm{~min}$ to inactivate the enzyme. Real-time PCR was carried out as previously described by McBeath et al. (2006), using $1 \mu$ lysate and the Lepeophtheirus salmonis assay only. Negative and inconclusive results were re-analysed using both the L. salmonis and Caligus elongatus von Nordmann 1832 assays. A threshold cycle value $\left(C_{\mathrm{T}}\right)$ result of $<32$ was classed as positive and $>32$ was classed as inconclusive.

Testing for differences in Lepeophtheirus salmonis densities. Due to highly dispersed counts at several stations, the coefficient of variation $(\mathrm{CV})$ of the mean density of larval sea lice during Cycle 1 was $>50 \%$. Thus, it was impossible to detect a difference in mean densities between Cycles 1 and 2 by estimating mean density directly from the data.

A more sensitive test is to model the mean density and compare the modeled means. Following Penston et al. (2008a,b) larval Lepeophtheirus salmonis density was modeled continuously through Cycles 1 and 2 with a generalized additive model (GAM; Wood 2006). Larval counts are assumed to follow a negative binomial distribution. We modelled density directly by using a log link with log sample volume as an offset. A smooth function (thin plate regression spline with a maximum of 9 degrees of freedom) was used to describe the trend in time. A small number, at most 0.003 larvae $\mathrm{m}^{-3}$, was added to the counts of some stations to alleviate problems with numerical stability caused by continuous periods of zero counts.

To test for a difference in mean density between cycles, a parametric bootstrap approach was used (Davidson \& Hinkley 1997). Using the regression coefficients and their variance-covariance matrix, $R=9999$ density curves were simulated representing the distribution of the estimated density trend. For each simulation, the mean in each cycle can be estimated by integrating, or summing up, the density curve from each cycle. In practice, the approximate mean from each cycle was calculated by numerical integration: predicting over a fine grid of time and taking the average for each cycle $\left(\bar{x}_{1}\right.$ and $\bar{x}_{2}$ ). The $\mathrm{p}$-value for the 2 -tailed test of the null hypothesis that the mean densities in the 2 cycles are equal is

$$
\mathrm{p}=2 \times \frac{1+\min \left(\sum_{i=1}^{R} \mathrm{I}\left(t_{i}>0\right), \sum_{i=1}^{R} \mathrm{I}\left(t_{i}<0\right)\right)}{1+R}
$$

where $R=9999, t_{i}$ is the comparison $\bar{x}_{1}>\bar{x}_{2}$ for the $i$ th simulation and $I(t>0)$ is the indicator function for the event $t>0$, which takes the value 1 when the event is true and zero otherwise; see for example Davidson \& Hinkley (1997).

\section{RESULTS}

Approximately half (48\%) of the plankton samples that contained nauplii also contained copepodids and $39 \%$ of samples containing copepodids also contained nauplii. A maximum of $13 \%$ (8) of the nauplii were possibly not Lepeophtheirus salmonis. The 3 nauplii 
Table 1. Lepeophtheirus salmonis, Caligus elongatus, and Lernaeenicus sprattae. Identification of numbers of copepodids (by microscopy) and nauplii (by real-time PCR). Percentages of each life stage total are given in parentheses. N/A: not applicable

\begin{tabular}{|lccccc|}
\hline & L. salmonis & C. elongatus & Negative & Inconclusive & L. sprattae \\
\hline Nauplii & $53(87)$ & $1(2)$ & $3(5)$ & $4(7)$ & N/A \\
Copepodids & $140(99)$ & 0 & N/A & N/A & $1(1)$ \\
\hline
\end{tabular}

(Table 2). Stns E and A had relatively low nauplius fractions, although the fraction increased at Stn E in Cycle 2. In Cycle 2, the lowest nauplius fraction occurred at Stn $\mathrm{H}$, almost matching the 0.00 value found in Cycle 1 at Stn A, the station most distant from the farm sites.

Statistically significant increases that tested negative for both Lepeophtheirus salmonis and Caligus elongatus (Table 1) were all found at different stations and during different years. The 4 nauplii that were inconclusively identified were from 3 different stations and no other louse larvae were found in these samples. The $C_{\mathrm{T}}$ values of these samples were too high to be confidently said to be, based on previous experience (A. J. A. McBeath pers. obs.), a 'true' positive. Over $85 \%$ of the nauplii analysed molecularly were identified as L. salmonis. One copepodid was identified morphologically as Lernaeenicus sprattae (Sowerby); all the others were identified as L. salmonis.

Across all stations, 192 nauplii and 269 copepodids were recovered in Cycle 1 and 679 nauplii and 1065 copepodids were recovered in Cycle 2. In Cycle 1, densities of larval lice were low at all sampling stations, except Stn $\mathrm{H}$, near the relocating farm. In Cycle 2, densities of larval lice were higher at several of the sampled stations (Fig. 2). In Cycle 1, nauplii were absent or present in low densities at Stns A and E while the greatest mean densities of nauplii and copepodids were found at Stn H (Table 2). The mean densities of nauplii and copepodids found at all stations in Cycle 2 were greater than in Cycle 1, except at Stn H. In Cycle 2, the greatest mean densities of nauplii were recovered at stations near farms ( $C$ and $G$ ), while the greatest mean densities of copepodids were recovered at Stns G and A, the latter of which was furthest from the farm sites. Although a relatively high mean density of copepodids was evident at Stn $A$, the mean density of nauplii at that station was the second lowest found in Cycle 2 (Table 2).

In Cycles 1 and 2, the highest nauplius fraction occurred at Stns C and G (adjacent to farms) with a lower fraction near Stn $\mathrm{H}$ in Cycle 1 (the relocating farm site), which fell close to zero in Cycle 2 in densities of nauplii were observed at Stns C, G and E in Cycle 2 compared to Cycle 1 (Table 3). At Stn A (furthest from farm sites), no significant increase was found between cycles, while at Stn $\mathrm{H}$ (the vacated farm site) the nauplius density decreased significantly between cycles. Similar to the trends for nauplius densities, in Cycle 2 compared to Cycle 1 the copepodid densities increased significantly at all stations
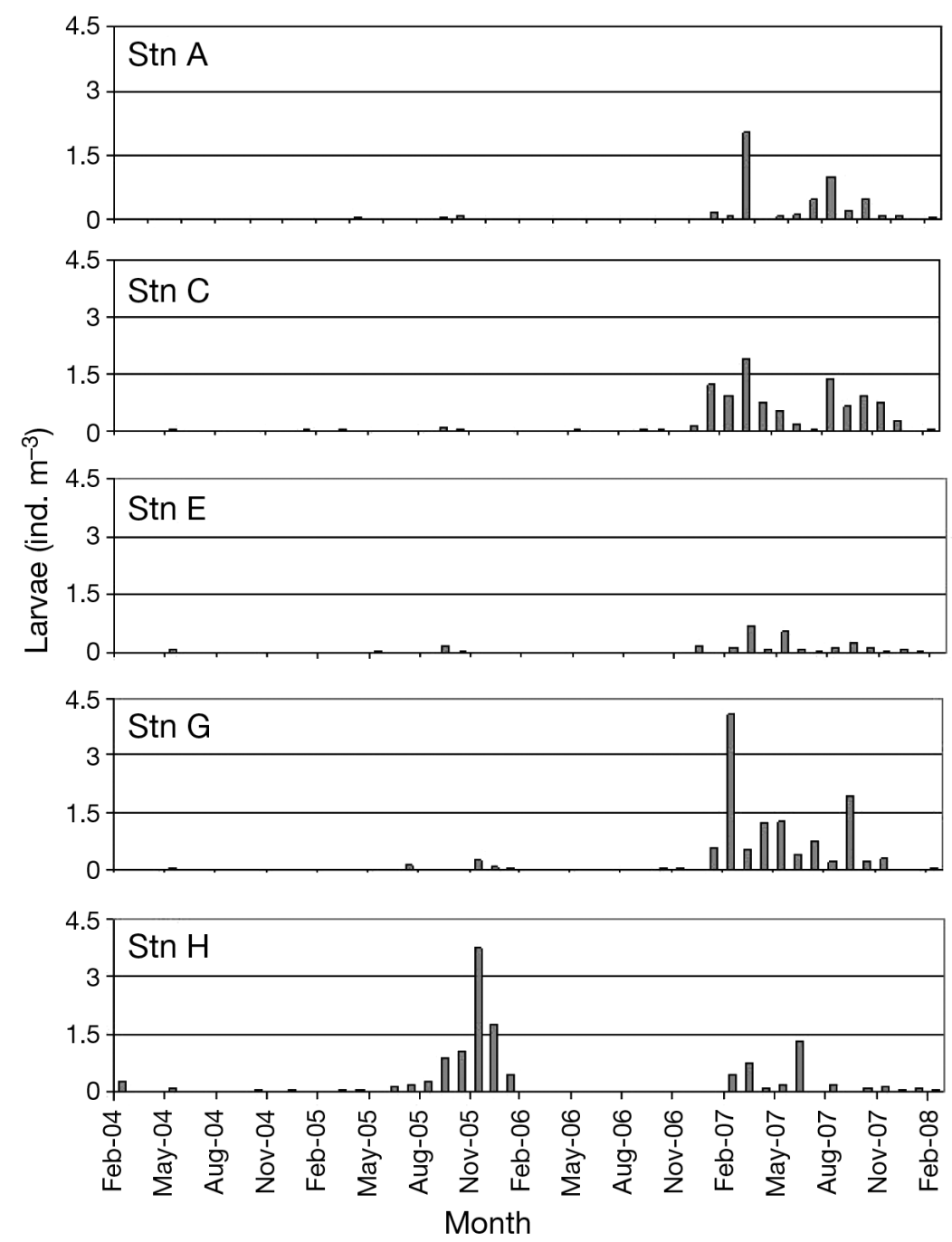

Fig. 2. Lepeophtheirus salmonis. Time series of mean monthly densities of total $L$. salmonis larvae (nauplii + copepodids $\mathrm{m}^{-3}$ ) recovered at sampling stations A, C, E, G and H between February 2004 and February 2008 
Table 2. Lepeophtheirus salmonis. Number of samples (N) collected, mean densities of nauplii (n) and copepodids (c) sampled and the nauplius fraction $(\mathrm{n}: \mathrm{n}+\mathrm{c})$ at sampling stations A, C, E, G and H during Cycle 1 (February 2004 to February 2006) and Cycle 2 (February 2006 to February 2008). Mean densities are total counts/total sampled volume over each production cycle at each station

\begin{tabular}{|lcccc|}
\hline Stn & $\mathrm{N}$ & $\begin{array}{c}\text { Nauplii } \\
\text { (ind. } 1000 \mathrm{~m}^{-3} \text { ) }\end{array}$ & $\begin{array}{c}\text { Copepodids } \\
\text { (ind. } 1000 \mathrm{~m}^{-3} \text { ) }\end{array}$ & $\mathrm{n}: \mathrm{n}+\mathrm{C}$ \\
\hline Cycle 1 & & & & \\
$\mathrm{A}$ & 57 & 0.00 & 18.36 & 0.00 \\
$\mathrm{C}$ & 56 & 15.20 & 5.70 & 0.73 \\
$\mathrm{E}$ & 54 & 1.05 & 11.50 & 0.08 \\
$\mathrm{G}$ & 53 & 20.12 & 7.54 & 0.73 \\
$\mathrm{H}$ & 52 & 202.43 & 290.28 & 0.40 \\
Total & $\mathbf{2 7 2}$ & & & \\
Cycle 2 & & & & \\
A & 50 & 7.17 & 181.15 & 0.04 \\
C & 50 & 228.02 & 131.11 & 0.63 \\
E & 47 & 30.60 & 65.90 & 0.32 \\
G & 45 & 189.66 & 223.86 & 0.46 \\
H & 38 & 2.78 & 147.96 & 0.02 \\
Total & $\mathbf{2 3 0}$ & & & \\
\hline
\end{tabular}

Table 3. Statistical differences between densities of nauplii and copepodids at sampling stations (A, C, E, G and H) in Cycle 2 (February 2006 to February 2008) compared to Cycle 1 (February 2004 to February 2006). Significant $\mathrm{p}$-values $(\mathrm{p}<0.05)$ are given in bold, assessed according to the Holm-Bonferonni method for multiple comparisons (Holm 1979). Plus and minus signs indicate positive and negative differences

\begin{tabular}{|lcc|}
\hline Stn & Nauplii & Copepodids \\
\hline A & +0.1408 & $\mathbf{+ 0 . 0 0 2 1}$ \\
C & $\mathbf{+ 0 . 0 0 2 4}$ & $\mathbf{+ 0 . 0 0 0 1}$ \\
E & $\mathbf{+ 0 . 0 1 1 8}$ & +0.0678 \\
G & $\mathbf{0 . 0 0 3 4}$ & $\mathbf{+ 0 . 0 0 1 0}$ \\
H & $\mathbf{- 0 . 0 0 4 4}$ & -0.9634 \\
\hline
\end{tabular}

except at Stns E and H. At Stn E the increase observed was not significant, while at Stn $\mathrm{H}$ the Cycle 2 densities of copepodids decreased relative to Cycle 1 , though not significantly.

\section{DISCUSSION}

The relocation of the salmon farm at Stn $\mathrm{H}$ brought about a significant reduction in the densities of nauplii at the site of the removed farm, but no significant reduction in infection pressure, as represented by densities of the infectious copepodid stage, was observed at that site. We discuss the significance of these findings and possible implications for the management of Atlantic salmon farms and wild salmonid fisheries.
The 4 nauplii inconclusively identified had $C_{\mathrm{T}}$ values that were improbably high. Real-time PCR is an extremely sensitive method and high- $C_{\mathrm{T}}$-value false positives can be produced from minuscule quantities of DNA within a sample. These very small DNA quantities likely result from tissue fragments of other larvae entering the pre-lysis tubes. The 3 nauplii that were negative for both the Lepeophtheirus salmonis and Caligus elongatus probes could have been other caligid copepods. All the remaining nauplii and copepodids analysed were identified as L. salmonis. Previous studies of planktonic sea lice in the Loch Torridon system similarly found L. salmonis to represent the major component of the louse larvae recovered (McKibben \& Hay 2004, Penston et al. 2008a,b, Penston \& Davies 2009, Kilburn et al. 2010). Given the evident predominance of L. salmonis in the sub-samples, we assumed the majority of the louse larvae recovered in this study were that species.

Previous surveys for planktonic louse larvae determined that the regular recovery of nauplii, which only persist for about $4 \mathrm{~d}$ at $10^{\circ} \mathrm{C}$ before developing to the copepodid stage (Johnson \& Albright 1991), is indicative of an important source of louse larvae nearby to those sampling stations (Costelloe et al. 1995, 1998a,b, Penston et al. 2004, 2008a,b). To investigate whether the relocation of the farm had any effect on the distribution of larval sea lice at the vacated site (Stn $\mathrm{H}$ ), we compared the densities and stages of the larvae at that location before and after the relocation. In Cycle 1, mean densities of nauplii and copepodids at Stn $\mathrm{H}$ were over an order of magnitude greater than at other stations. Whereas in Cycle 2, after the biomass of Farm 2 (near Stn H) had been relocated to Farm 3 (near Stn G), the densities of nauplii adjacent to the vacated site were lower than at any other station. The copepodid densities at the vacated site (Stn $\mathrm{H}$ ) in Cycle 2 were the third lowest of all of the sampled stations. The high mean density of nauplii found during Cycle 1 at Stn $\mathrm{H}$ (near Farm 2), indicated a local source of larval lice during that period. This contrasted with the low mean density of nauplii found there in Cycle 2, after Farm 2 was removed, which indicated the absence of a nearby source of lice.

Earlier studies in the Loch Torridon system found that salmon farms can be a major source of lice (Penston et al. 2008a,b, Penston \& Davies 2009). Given that Stn $\mathrm{H}$ was situated adjacent to Farm 2 (before it was relocated), it is very likely that the larvae, particularly the nauplii, recovered at that station originated from adults at Farm 2. What is important to note is that although mean densities of the infectious copepodids were $50 \%$ lower in Cycle 2 compared to Cycle 1, a moderate density was still observed at that location and the decrease was not statistically significant. 
Therefore, the farm relocation did not result in a significant reduction in infection pressure, as represented by densities of the infectious copepodid stage, at Stn $\mathrm{H}$.

Although lower than at Stns C and G (near other farm sites), the nauplius fraction at Stn $\mathrm{H}$ was still high in Cycle 1 relative to that at Stns A and E (situated further from the farms). The nauplius fraction at $\mathrm{Stn} \mathrm{H}$ in Cycle 2 was approximately zero, similar to the low fraction at Stn A, which was the station most remote from farms. These low fractions consistently indicated the absence of a nearby source of lice. However, as discussed later, variation in the nauplius fraction at any one location will also be influenced by the local hydrography (including wind-generated surface currents) and topography.

Rapidly metamorphosing nauplii will generally be found in higher densities closer to a lice source. The nauplius fraction at each station provides an index to assess the proximity of a major source of Lepeophtheirus salmonis larvae. The index is indicative only, given that hydrographic conditions vary between stations. Stations adjacent to farms were found to have a greater nauplius fraction than stations more distant from farms ( $\sim 2 \mathrm{~km}$ in this instance). Earlier studies found no nauplii at the mouth of the River Shieldaig which is $4.6 \mathrm{~km}$ from the nearest Atlantic salmon farm (McKibben \& Hay 2004, Penston et al. 2004). Costelloe et al. (1996) also found a similar pattern with samples collected closer to an Atlantic salmon farm having a greater proportion of nauplii to copepodids than samples collected distant from that farm. The ratios presented in the present study are consistent with those seen previously in this area; higher close to the farms and lower at stations further away from them (Penston et al. 2004, 2008b). This consistency in the pattern observed using this nauplius fraction over time and space supports its wider application as an index of proximity to sources of lice.

At all stations, the sampled densities of nauplii and/or copepodids increased significantly in Cycle 2 compared to Cycle 1, except at Stn $\mathrm{H}$ from where the farm (Farm 2) was removed. It is of interest to consider whether this may have been influenced by the farm relocation. These increased densities were most likely due to an increase in the number of lice being released from the local Atlantic salmon farms, as the farms were found to represent the greatest source of lice in the area (Penston \& Davies 2009). The most likely causes of increased louse production at the farms were (1) changes in the environmental conditions affecting louse growth and survival, (2) changes in the efficacy of louse treatments (the ability of chemotherapeutants to remove lice), and (3) the increase in the size of Farm 3.

Low salinity levels $(<29)$ can compromise the survival of Lepeophtheirus salmonis larvae (Bricknell et al. 2006). However, it is unlikely that salinity fluctuations between cycles could account for the change in larvae densities, since the sea water remains near full salinity strength in the Loch Torridon system as a result of low freshwater input (Murray \& Gillibrand 2006, Amundrud \& Murray 2009). Although an increase in temperature can increase the growth rate of lice (Johnson \& Albright 1991), measurements made in the Loch Torridon system between February 2004 and June 2007 showed that sea surface temperatures (mean \pm SD: $10.5 \pm 2.0^{\circ} \mathrm{C}$ ) did not increase significantly between the observed production cycles (Penston \& Davies 2009). It seems unlikely, therefore, that the increase in louse densities between Cycles 1 and 2 was due to changing environmental conditions.

The observed increase in louse densities between Cycles 1 and 2 may in part be explained by the efficacy of louse treatments and this should be considered independent of the farm relocation. In the Loch Torridon system between the production cycles of 20022003 and 2004-2005 (the latter spanning the present Cycle 1), a significant decrease in the densities of Lepeophtheirus salmonis larvae was described by Penston et al. (2008b). This decrease was attributed to applications of emamectin benzoate at Farm 1. In 2007, for the first time in the Loch Torridon management area, the numbers of gravid lice on farmed Atlantic salmon did not decrease in response to applications of emamectin benzoate, perhaps as a result of ineffective treatments (Penston \& Davies 2009). Numbers of ineffective emamectin benzoate louse treatments increased at Atlantic salmon farms in Scotland from 2002 to 2006 (Lees et al. 2008).

While exchange of larvae may occur between all 3 basins in the Loch Torridon system, transport of larvae is not equally likely in all directions. In Cycle 1, when louse larvae were being produced in high numbers by Farm 2 in the Lower Loch Torridon basin, low densities of both nauplii and copepodids were found in the Loch Shieldaig and Upper Loch Torridon basins. This suggest that few, if any, larvae were transported from Farm 2 to the upper basins in Cycle 1. These findings are supported by predictions of a coupled hydrodynamic-particle model developed for the Loch Torridon system, which indicated that few lice released from farms in Lower Loch Torridon would be transported towards Loch Shieldaig or Upper Loch Torridon (Amundrud \& Murray 2009). The factor limiting the landward transport of larvae from $\mathrm{Stn} \mathrm{H}_{\text {, near the loca- }}$ tion of Farm 2, is local topography; the area is enclosed by steep cliffs on 3 sides giving it an amphitheatre appearance facing seawards.

In contrast with Cycle 1, louse larvae were being produced in high numbers by Farms 1 in Loch Shieldaig and Farm 3 in Upper Loch Torridon during Cycle 2. 
These louse larvae may have been transported from the inner basins to Stn $\mathrm{H}$, where they appeared in our samples as copepodids. Amundrud \& Murray (2009) predicted that larval lice released at locations throughout Loch Shieldaig and Upper Loch Torridon can be transported to the proximity of Stn H in the Lower Loch Torridon basin. It is unlikely that the copepodids recovered at $\mathrm{Stn} \mathrm{H}$ in Cycle 2, or anywhere within the Loch Torridon management area during the present study, were transported there from farms in neighbouring management areas as the closest ones are $>30 \mathrm{~km}$ distant. A 10-yer study of sea lice infection on sea trout on the west coast of Ireland indicated that lice could disperse up to between 25 and $30 \mathrm{~km}$ from farms (Gargan et al. 2003), and most sea lice dispersal models do not predict larvae to travel $>30 \mathrm{~km}$ (Krkošek et al. 2005, Murray \& Gillibrand 2006, Gillibrand \& Willis 2007, Amundrud \& Murray 2009).

\section{CONCLUSIONS AND IMPLICATIONS}

The findings of the present study have implications for the salmon aquaculture industry and for wild salmonid fisheries. The removal of Farm 2 from Lower Loch Torridon led to a significant reduction in the production of Lepeophtheirus salmonis nauplii at the vacated site. Despite this, L. salmonis larvae were transported to that site from elsewhere in Cycle 2. The most likely source of the larvae transported to the vacated site (Stn $\mathrm{H}$ ) was one or more of the other farms in the Torridon management area. These other farms were $\sim 5$ to $8 \mathrm{~km}$ distant from the site of the removed farm, indicating that the larvae were transported at least 5 to $8 \mathrm{~km}$, and possibly further. Therefore, in terms of louse control, sites within a conservative distance of $8 \mathrm{~km}$ of one another may not be considered independent in this system, and the Torridon management area should be, and is, $>8 \mathrm{~km}$ from the neighbouring management areas. Separation distances are likely to vary with differences in hydrographic constraints and connectedness between management areas; nevertheless, the findings in this area should be taken into consideration elsewhere. Our study indicates that if farm relocation is being considered, with a view to reducing louse abundance, then possible transport of $L$. salmonis larvae from neighbouring farms to the area of concern must be considered.

Acknowledgements. Thanks to our colleagues connected with the Shieldaig Field Station who made gathering this long dataset possible: D. Hay, J. Raffell, S. Buttle and A. Moys. Thanks also to S. Hay, C. Collins, S. Middlemas and C. Pert, and to 3 journal referees for providing constructive critical comments on the manuscript.

\section{LITERATURE CITED}

Amundrud TL, Murray AG (2009) Modelling sea lice under varying environmental forcing in Loch Torridon, a Scottish sea loch. J Fish Dis 32:27-44

Anonymous (2006) A code of good practice for Scottish finfish aquaculture. Scottish Salmon Producers' Organisation, Perth

Bricknell IR, Dalesman SJ, O'Shea B, Pert CC, Mordue Luntz JA (2006) Effect of environmental salinity on sea lice Lepeophtheirus salmonis settlement success. Dis Aquat Org 71:201-212

Bron JE, Sommerville C, Wootten R, Rae GH (1993) Fallowing of marine Atlantic salmon, Salmo salar L., farms as a method for the control of sea lice, Lepeophtheirus salmonis (Krøyer, 1837). J Fish Dis 16:487-493

Bruno DW, Stone J (1990) The role of saithe, Pollachius virens L., as a host for the sea lice Lepeophtheirus salmonis Krøyer and Caligus elongatus Nordmann. Aquaculture 89: 201-207

Connors BM, Krkošek M, Dill LM (2008) Sea lice escape predation on their host. Biol Lett 4:455-457

> Costello MJ (2009a) How sea lice from salmon farms may cause wild salmonid declines in Europe and North America and be a threat to fishes elsewhere. Proc Biol Sci 276: 3385-3394

> Costelloe J, Costelloe M, Roche N (1995) Variation in sea lice infestation on Atlantic salmon smolts in Killary Harbour, West Coast of Ireland. Aquacult Int 3:379-393

Costelloe M, Costelloe J, Roche N (1996) Planktonic dispersion of larval salmon-lice, Lepeophtheirus salmonis, associated with cultured salmon, Salmo salar, in Western Ireland. J Mar Biol Assoc UK 76:141-149

Costelloe M, Costelloe J, Coghlan N, O'Donohoe G, O'Connor B (1998a) Distribution of the larval stages of Lepeophtheirus salmonis in three bays on the west coast of Ireland. ICES J Mar Sci 55:181-187

> Costelloe M, Costelloe J, O'Donohoe G, Coghlan NJ, Oonk M, van der Heijden Y (1998b) Planktonic distribution of sea lice larvae, Lepeophtheirus salmonis, in Killary Harbour, west coast of Ireland. J Mar Biol Assoc UK 78: 853-874

Davidson AC, Hinkley DV (1997) Bootstrap methods and their application. Cambridge University Press, Cambridge

Finstad B, Bjørn PA, Grimnes A, Hvidsten NA (2000) Laboratory and field investigations of salmon lice [Lepeophtheirus salmonis (Krøyer)] infestation on Atlantic salmon (Salmo salar L.) post-smolts. Aquacult Res 31:795-803

Ford JS, Myers RA (2008) A global assessment of salmon aquaculture impacts on wild salmonids. PLoS Biol 6:e33

Gargan PG, Tully O, Poole R (2003) The relationship between sea lice infestation, sea lice production and sea trout survival in Ireland, 1992-2001. In: Mills D (ed) Salmon on the edge. Blackwell Science, Oxford, p 119-135

Gillibrand PA, Amundrud TL (2007) A numerical study of the tidal circulation and buoyancy effects in a Scottish fjord: Loch Torridon. J Geophys Res 112:C05030 doi:10.1029/ 2006JC003806

Gillibrand PA, Willis KJ (2007) Dispersal of sea louse larvae from salmon farms: modelling the influence of environmental conditions and larval behaviour. Aquat Biol 1: 63-75

Grant AN, Treasurer JW (1993) The effects of fallowing on caligid infestations on farmed Atlantic salmon (Salmo salar L.) in Scotland. In: Boxshall GA, Defaye D (eds) Pathogens of wild and farmed fish: sea lice. Ellis Horwood, Chichester, p 225-260 
Holm S (1979) A simple sequentially rejective multiple test procedure. Scand J Stat 6:65-70

Johnson SC, Albright LJ (1991) Development, growth and survival of Lepeophtheirus salmonis (Copepods: Caligidae) under laboratory conditions. J Mar Biol Assoc UK 71: 425-436

Kilburn R, Bricknell IR, Cook P, Pert CC, Dunn J, Matejusova I (2010) Design and application of a portable, automated plankton sampler for the capture of the parasitic copepods Lepeophtheirus salmonis (Krøyer 1837) and Caligus elongatus (Von Nordmann 1832). J Plankton Res 32:967-970

Krkošek M, Lewis MA, Volpe JP (2005) Transmission dynamics of parasitic sea lice from farm to wild salmon. Proc Biol Sci 272:689-696

Lees F, Baillie M, Gettinby G, Revie CW (2008) Factors associated with changing efficacy of emamectin benzoate against infestations of Lepeophtheirus salmonis on Scottish salmon farms. J Fish Dis 31:947-951

McBeath AJA, Penston MJ, Snow M, Cook PF, Bricknell IR, Cunningham CO (2006) Development and application of real-time PCR for specific detection of Lepeophtheirus salmonis and Caligus elongatus larvae in Scottish plankton samples. Dis Aquat Org 73:141-150

McKibben MA, Hay DW (2004) Distributions of planktonic sea lice larvae Lepeophtheirus salmonis in the inter-tidal zone in Loch Torridon, Western Scotland in relation to salmon farm production cycles. Aquacult Res 35:742-750

Middlemas SJ, Raffell JA, Hay DW, Hatton-Ellis M, Armstrong JD (2010) Temporal and spatial patterns in sea lice levels on sea trout in Western Scotland in relation to fish farm production cycles. Biol Lett 6:548-551

Murray AG (2009) Using simple models to review the application and implications of different approaches used to simulate transmission of pathogens among aquatic animals. Prev Vet Med 88:167-177

Murray AG, Gillibrand PA (2006) Modelling salmon lice dispersal in Loch Torridon, Scotland. Mar Pollut Bull 53: 128-135

Penston MJ, Davies IM (2009) An assessment of salmon farms and wild salmonids as sources of Lepeophtheirus salmonis (Krøyer) copepodids in the water column in Loch Torridon, Scotland. J Fish Dis 32:75-88

Penston MJ, McKibben MA, Hay DW, Gillibrand PA (2004) Observations on open-water densities of sea lice larvae in Loch

Editorial responsibility: Bengt Finstad,

Trondheim, Norway
Shieldaig, Western Scotland. Aquacult Res 35:793-805

> Penston MJ, Millar CP, Zuur A, Davies IM (2008a) Spatial and temporal distribution of Lepeophtheirus salmonis (Krøyer) larvae in a sea loch containing Atlantic salmon, Salmo salar (L.), farms on the north-west coast of Scotland. J Fish Dis 31:361-371

Penston MJ, Millar CP, Davies IM (2008b) Reduced Lepeophtheirus salmonis larval abundance in a sea loch on the west coast of Scotland between 2002 and 2006. Dis Aquat Org 81:109-117

Pert C, Urquhart K, Bricknell I (2006) The sea bass (Dicentrarchus labrax L.) a peripatetic host of Lepeophtheirus salmonis (Copepoda: Caligidae)? Bull Eur Assoc Fish Pathol 26:163-165

Revie C, Dill L, Finstad B, Todd C (2009) Salmon Aquaculture Dialogue Working Group report on sea lice. Commissioned by the Salmon Aquaculture Dialogue. World Wildlife Fund, Washington, DC, available at http://www. worldwildlife.org/what/globalmarkets/aquaculture/WWF Binaryitem11790.pdf

Rosenberg AA (2008) The price of lice. Nature 451:23-24

Schram TA (2004) Practical identification of pelagic sea lice larvae. J Mar Biol Assoc UK 84:103-110

Tully O, Whelan KF (1993) Production of nauplii of Leopepotheirus salmonis (Krøyer) (Copepoda: Caligidae) from farmed and wild salmon and its relation to the infestation of wild sea trout (Salmo trutta L.) off the west coast of Ireland in 1991. Fish Res 17:187-200

Tully O, Poole WR, Whelan KF, Merigoux S (1993) Parameters and possible causes of epizootics of Lepeophtheirus salmonis (Krøyer) in relation to origin and water temperature. In: Boxshall GA, Defaye D (eds) Pathogens of wild and farmed fish: sea lice. Ellis Horwood, Chichester, p 202-213

Walker AF (1994) Sea trout and salmon stocks in the Western Highlands. In: Shelton RGJ (ed) Problems with sea trout and salmon in the Western Highlands. Atlantic Salmon Trust, Pitlochry, p 6-18

Whelan KF (1993) Decline of sea trout in the west of Ireland: an indication of forthcoming marine problems for salmon? In: Mills D (ed) Salmon in the sea; and new enhancement strategies. Fishing News Books, Edinburgh, p 171-183

Wood S (2006) Generalized additive models, an introduction with R. Chapman \& Hall, London

Submitted: December 15, 2010; Accepted: March 9, 2011 Proofs received from author(s): April 4, 2011 